\title{
Profiling of Cholinesterase Extracted from The Brain Tissue of Diodon hystrix and Its Inhibition Reaction Towards Carbamates
}

\author{
Akid Haris ${ }^{1}$, Noreen Nordin ${ }^{1}$, Nur Azizah Mustapa ${ }^{1}$, Suraya Abd. Sani ${ }^{1}$, \\ Mohd Yunus Shukor ${ }^{2}$ and Mohd Khalizan Sabullah ${ }^{1 *}$ \\ ${ }^{1}$ Faculty of Science and Natural Resources, University Malaysia Sabah, Jalan UMS, \\ 88400 Kota Kinabalu, Sabah, Malaysia \\ ${ }^{2}$ Faculty of Biotechnology and Biomolecular Sciences, Universiti Putra Malaysia, \\ 43400 UPM Serdang, Selangor Darul Ehsan, Malaysia
}

\begin{abstract}
Diodon hystrix, commonly known as spot-fin porcupine fish is a salt-water fish belonging to the Diodontidae family. It is widely distributed in Sabah wet market due to its commercial value. This study exploits the effectiveness of Cholinesterase (ChE) obtained from the brain tissue of $D$. hystrix in detecting carbamates inhibitory activities. Carbamate pesticides known to inhibit $\mathrm{ChE}$ and toxic towards living organisms can contaminate the water bodies. By using diethylaminoethanol (DEAE) Sepharose ion exchange chromatography, a total of $40 \%$ recovery yield of $\mathrm{ChE}$ was obtained with a 165.77 purification fold. Furthermore, the ChE showed a high affinity towards acetylthiocholine iodide (ATC) with an optimum activity at $\mathrm{pH} 7.45$ and temperature ranging from 20 to $40^{\circ} \mathrm{C}$. Among five different types of carbamates, methomyl was found to have the highest percentage of inhibition analyzed using ChE inhibitory assay, followed by carbofuran, bendiocarb, carbaryl and propoxur with $>85 \%$ inhibition rate. The results concluded that ChEs extracted from the brain tissue of $D$. hystrix are applicable to be used as a bioindicator in detecting the presence of carbamates.
\end{abstract}

ARTICLE INFO

Article history:

Received: 10 February 2020

Accepted: 13 November 2020

Published: 31 December 2020

DOI: https://doi.org/10.47836/pjst.28.S2.08

E-mail addresses:

akidharis96@gmail.com (Akid Haris)

ryeennordin@yahoo.com (Noreen Nordin)

izzah0506@yahoo.com (Nur Azizah Mustapa)

suraya.abdulsani@ums.edu.my (Suraya Abd. Sani)

yunus.upm@gmail.com (Mohd Yunus Shukor)

khalizan@ums.edu.my (Mohd Khalizan Sabullah)

* Corresponding author
Keywords: Carbamates, cholinesterase, diodon hystrixion, exchange chromatography, inhibitory activities, water pollution

\section{INTRODUCTION}

Almost all of today's applications require water such as in agriculture, industrial, animal husbandry, tourism, fishery and even simple individual tasks. However, unethical use of water resources is becoming worse 
and this threatens the quality of water which will slowly and surely get more polluted with time (Gonzalez et al., 2009). The pollution of water bodies from direct and indirect use of natural or artificial compounds, such as carbamates can be toxic to the human body due to its ability to inhibit cholinesterase enzyme (ChE) (Hayat et al., 2015). In order to curb this issue, water monitoring and rehabilitation are needed. A fast, cost-effective and reliable way of contamination screening before using high-performance technology such as High Pressure Liquid Chromatography (HPLC) can help ease this process.

$\mathrm{ChE}$ is an enzyme responsible for lysing choline base esters which serve as neurotransmitters found in animals. This enzyme can be subdivided into acetylcholinesterase (AChE), butyrylcholinesterase (BChE) and propionyl cholinesterase (PChE) with PChE being closely related to $\mathrm{BChE}$ (Ahmad et al., 2016). The most apparent difference between $\mathrm{AChE}$ and $\mathrm{BChE}$ is their ligand-binding specificity due to the difference in the number of aromatic residues in their gorge (Rosenberry et al., 2017). Nonetheless, all three sub-types of ChE are susceptible towards carbamate inhibitory activities which disable them from hydrolyzing choline-based esters.

Carbamate pesticides are widely used to control the development of pests through inhibition of cholinesterase activities, with high acute toxicity similar to the organophosphates (OP). Carbamates and OP differ in their mode of action during the formation of the ChE-inhibitor complex. OP are irreversible inhibitors where after being phosphorylated in ChE, cannot be reversed. Carbamates, on the other hand, are temporary or reversible inhibitors where decarbamylation via spontaneous hydrolysis would shorten the inhibition time (Darvesh et al., 2008). When AChE is inhibited in the body, acetylcholine will accumulate in synapses which can cause severe central nervous system disorder (Berman et al., 2017).

The bioaccumulation of toxicants in marine organisms causes severe effects to the fish, handlers and also humankind (Almroth, 2008). Multiple past studies had proven the sensitivity of fish towards toxicants (Monserrat et al., 2002; Sturm et al., 2000), making them a suitable biomarker. This study used $D$. hystrix mostly due to its availability and increasing commercial value in Sabah. It can be found at prices as low as RM 5 per kilogram but their commercial value in Sabah has been increasing in recent years, mostly as a delicacy for both tourists and locals. Other than that, D. hystrix interesting characteristics such its ability to host multiple endo and ectoparasites (Quilichini et al., 2010) with high survival endurance were also considered during the selection process. Observing the inhibition of ChE by pesticide in vitro helps to bypass detoxification defenses and bioactivation of compounds in non-target tissues (Assis et al., 2012). ChE based early-warning biomarker that was thoroughly researched and recently applied for pollution assessment showed tissue-specific variations in AChE responses towards inhibitors (Hayat et al., 2015). This can also be true for different species of fish. Hence, this study focused on the profiling of 
ChE extracted from the brain tissue of $D$. hystrix where AChE was concentrated to test its ability to detect carbamate inhibitory activities.

\section{MATERIALS AND METHODS}

\section{Chemicals}

The materials used in the study include Acetylthiocholine iodide (ATC), butyrylthiocholine iodide (BTC), propionyl thiocholine iodide (PTC), 5,5-dithio-bis-(2-nitrobenzoic acid) (DTNB), diethylaminoethanol-Sepharose (DEAE-Sepharose), Bradford solution and bovine serum albumin (BSA) were obtained from Sigma-Aldrich, Germany.

\section{Preparation of Crude Homogenate}

A total of three D. hystrix was obtained from the Kota Kinabalu Wet Market. Each fish was approximately $500-800 \mathrm{~g}$ in weight with $30-40 \mathrm{~cm}$ in length. After being killed, the brain was extracted and weighed. The crude brain sample was homogenized in $0.1 \mathrm{M}$ sodium phosphate buffer $\mathrm{pH} 7.5$ along with $2 \mathrm{mM}$ phenylmethylsulfonyl fluoride (PMSF) with the ratio of brain and buffer; $1: 4(\mathrm{w} / \mathrm{v})$. The homogenate was centrifuged at 10, $000 \mathrm{rpm}$ (11200 $\times g$ ) for 13 minutes at $4^{\circ} \mathrm{C}$. The supernatant was stored in a clean microcentrifuge tube at $-20^{\circ} \mathrm{C}$ after separating it from the pallet prior to further analysis (Ahmad et al., 2016).

\section{Partial Purification (Ion Exchange Chromatography)}

DEAE-Sepharose was loaded into a disposable desalting column with a $0.9 \mathrm{~cm}$ diameter and was allowed to settle giving a $3 \mathrm{~cm}$ bed height. The column was then washed with a five-batch volume of washing buffer ( $20 \mathrm{mM}$ sodium phosphate buffer, $\mathrm{pH} 7.5)$, cleaning the matrix and calibrating the flow rate. A total of $300 \mu \mathrm{L}$ of crude supernatant was loaded into the column before running another three-batch volumes of washing buffer into the column. Next, five batch volumes of elution buffer (20 mM sodium phosphate buffer containing increasing $\mathrm{NaCl}$ concentration from $0.2 \mathrm{M}$ to $1 \mathrm{M}$ ) was loaded into the column while simultaneously collecting $1 \mathrm{~mL}$ fractions until the end of the elution stage (Acikara, 2013). According to Ellman et al. (1961) and Bradford et al. (1976), enzyme activity and protein content determination are applied on all of the fractions collected with fractions showing high ChE activity combined (Sabullah et al., 2015).

\section{Enzyme Activity Determination}

The activity of ChE was determined using a 96 microplate well assay according to the method of Ellman et al. (1961) with a slight modification. This study used acetylthiocholine iodide (ATC) as a substrate for both $\mathrm{pH}$ and temperature profiling. A total of $20 \mu \mathrm{L}$ DTNB (0.067 mM), $200 \mu \mathrm{L}$ of $0.1 \mathrm{M}$ sodium phosphate buffer at $\mathrm{pH} 7.45$ and $10 \mu \mathrm{L}$ extracted $\mathrm{ChE}$ 
were loaded into the microplate wells and incubated at room temperature for 15 minutes. After that, $20 \mu \mathrm{L}$ of $0.5 \mathrm{mM}$ ATC was added, followed with another 10 minutes incubation at room temperature. The changes in colour of solution from colourless to yellow indicates a reaction. The enzyme activity was determined by calculating the quantity of substrate ( $\mu \mathrm{mol}$ ) hydrolyzed by ChE per minute and per protein ( $\mathrm{U}$ or $\mu \mathrm{molmin}^{-1} \mathrm{mg}^{-1}$ ) with 13.6 $\mathrm{mM}^{-1} \mathrm{~cm}^{-1}$ as extinction coefficient. Specific enzyme activity was indicated as $\mu$ mole $\mathrm{min}^{-1}$ $\mathrm{mg}^{-1}$ of protein or $\mathrm{Umg}^{-1}$ of protein. The assays were performed in the dark with each test done in triplicates.

\section{Substrate Specificity}

Acetylthiocholine iodide (ATC), butyrylthiocholine iodide (BTC) and propionyl thiocholine iodide (PTC) were the three synthetic substrates used in determining ChE specificity. The concentration of each substrate was set from 0.5 to $2.5 \mathrm{mM}$. The assay reaction mixture was incubated for 10 minutes at room temperature before the absorbance reading at $405 \mathrm{~nm}$ was taken (Sabullah et al., 2014). Biomolecular constant $\left(\mathrm{K}_{\mathrm{m}}\right)$ and maximum velocity $\left(\mathrm{V}_{\mathrm{m}}\right)$ was determined using Michaelis-Menten curves; plotted using GraphPad Prism Software version 5 .

\section{pH and Temperature Profiling}

The overlapping buffering system was applied to test $D$. hystrix optimum $\mathrm{pH}$. The buffers were comprised of acetate buffer (0.1 M; pH 3.0, 4.0 and 5.0), sodium phosphate buffer (0.1 M; pH 5.0, 6.0, 7.5 and 8.0) and Tris- $\mathrm{HCl}$ buffer (0.1 M; $\mathrm{pH} 7.5,8.0$ and 9.0). With reference to Ahmad et al. (2016), optimum temperature was deduced by incubating the reaction mixture at a selected temperature of $20,25,30,40,50$ and $60{ }^{\circ} \mathrm{C}$.

\section{ChE Inhibitory Assay}

The inhibitory effect of five types of carbamates, namely methomyl, carbofuran, bendiocarb, carbaryl and propoxur was tested by incubating them with D. hystrix ChE. Carbamates were selected due to its widespread use in agriculture to control pests and it could be toxic when they were discharged into the water bodies without proper treatment. The test mixture comprised $150 \mu \mathrm{L}$ sodium phosphate buffer $(0.1 \mathrm{M}, \mathrm{pH} 7.5), 50 \mu \mathrm{L}$ of carbamates with $10 \mathrm{ppm}$ final concentration, $20 \mu \mathrm{L}$ DTNB $(0.067 \mathrm{mM})$ and $10 \mu \mathrm{L}$ of extracted ChE. For control, carbamates were replaced with sodium phosphate buffer. The mixture was incubated for 15 minutes at room temperature before the addition of $20 \mu \mathrm{L}$ of substrate. It was then incubated again for 10 minutes at room temperature. Reading of absorbance was taken at $405 \mathrm{~nm}$ following 10 minutes incubation (Sabullah et al., 2015). ChE inhibition rates for each pesticide were then calculated using Equation 1. 
$\operatorname{Inhibition}(\%)=\frac{U c-U i}{U c}(100)$

Equation 1: Carbamates inhibition rate towards ChE (\%)

$U_{c}=$ Control enzyme activity

$U i=$ Enzyme activity with carbamates inhibition

\section{RESULTS AND DISCUSSIONS}

\section{Cholinesterase (ChE) Purification Profile}

Figure 1 shows the purification profile of $\mathrm{ChE}$ by comparing the enzyme activity and the protein fractions obtained from ion exchange chromatography. A total of 37 fractions were obtained, each with a total volume of $1 \mathrm{~mL}$. Fraction 14 displayed the highest ChE activity followed by fraction 12 and 13, while the highest protein concentration was observed in fraction 13. The low protein concentration with high enzyme activity on fraction 14 suggests that it has the highest amount of ChE. Fractions 12 to 16 were selected and combined for enzyme profiling due to their high enzyme activity and protein concentration. Table 1 shows the ChE specific activity and final yield of protein for each stage in the sample purification process from crude homogenate until the sample had gone through ion exchange chromatography.

Following the principle of anion-exchange gel chromatography of DEAE-Sepharose, it is understood that the positive charge matrix will exhibit ionic interaction towards a negative charge sample that passes through the column. Due to proteins having different

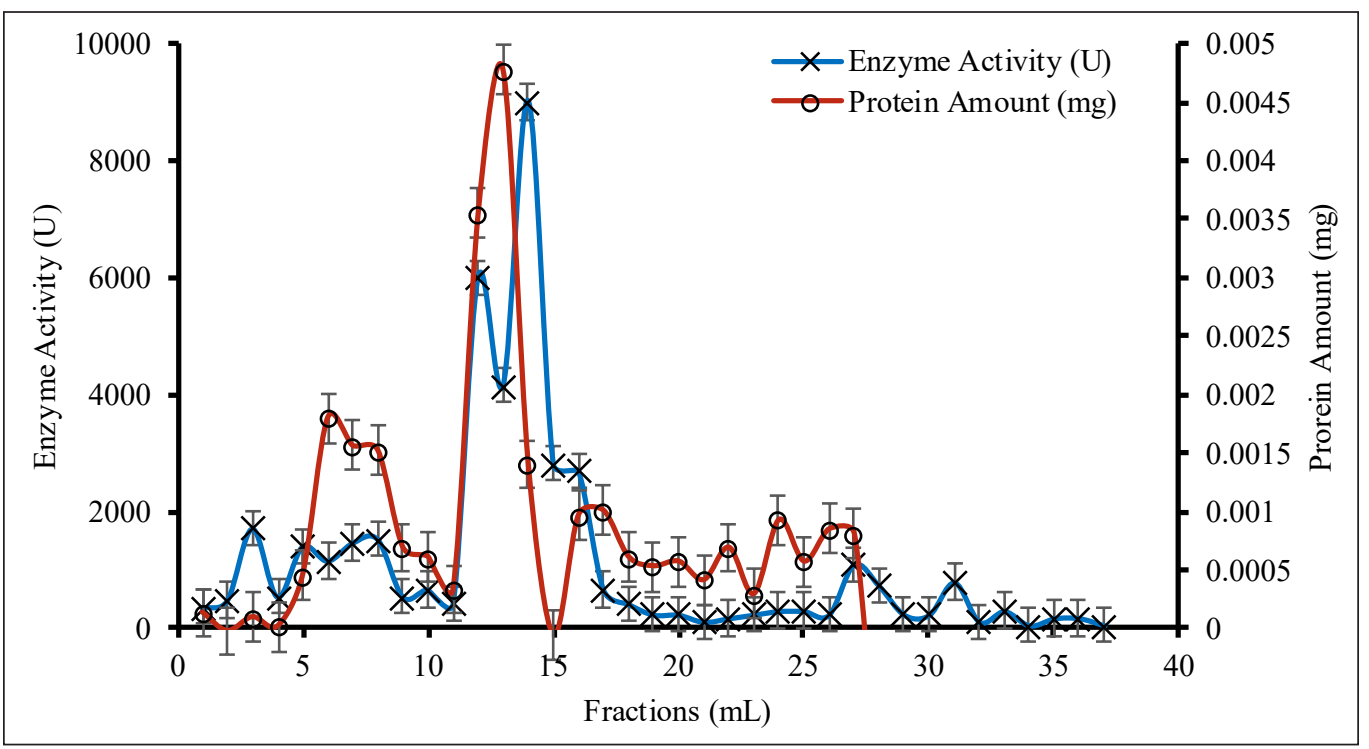

Figure 1. DEAE-Sepharose ion exchange chromatography profile on ChE purification from brain tissue of $D$. hystrix with error bars represented by mean \pm standard error $(\mathrm{n}=3)$ 
Table 1

ChE purification table of $\mathrm{D}$. hystrix. Specific activity displayed in $\left(U \mathrm{mg}^{-1}\right)$ indicates $\mu$ mole/min/mg protein

\begin{tabular}{lccccc}
\hline Sample & $\begin{array}{c}\text { Total protein } \\
(\mathbf{m g})\end{array}$ & $\begin{array}{c}\text { Total ChE } \\
\text { activity (U) }\end{array}$ & $\begin{array}{c}\text { Specific activity } \\
\left(\mathbf{U m g}^{-1}\right)\end{array}$ & $\begin{array}{c}\text { Purification } \\
\text { fold }\end{array}$ & $\begin{array}{c}\text { Yield } \\
(\%)\end{array}$ \\
\hline $\begin{array}{l}\text { Crude homogenate } \\
\begin{array}{l}\text { Supernatant } \\
\text { (centrifuged;11200g, }\end{array}\end{array}$ & 7.54 & 32720.59 & 4339.60 & 1.00 & 100 \\
$\begin{array}{l}\left.\mathbf{1 3} \text { minutes, } \mathbf{4}^{\mathbf{0}} \mathbf{C}\right) \\
\begin{array}{l}\text { DEAE Sepharose } \\
\text { sample extract }\end{array}\end{array}$ & 3.66 & 32169.12 & 8789.38 & 2.03 & 98.31 \\
\hline
\end{tabular}

total charge and ionic strength, separation of other proteins from the targeted $\mathrm{ChE}$ can be achieved. It is important to know the isoelectric point of the targeted enzyme in order to make sure the $\mathrm{ChE}$ is negatively charged. Thus, the sample solution needs to have $\mathrm{pH}$ higher than the isoelectric point of ChE, which is approximately \pm 5.35 (Bon and Rieger, 1975). Different concentrations of $\mathrm{NaCl}$ helps in eluting $\mathrm{ChE}$ by displacement of bound proteins through ions in the buffer competing for the binding site where further increase in ionic strength displaces proteins based on their charge strength (Acikara, 2013). Figure 1 shows the abundance of protein amounts in fraction 13, although low enzyme activity was observed opposite to that of fraction 14. This displayed the principle of ion-exchange chromatography very clearly. This study can be further proven in Table 1, which shows the drastic decrease in protein amount due to foreign proteins being filtered from $\mathrm{ChE}$ at different $\mathrm{NaCl}$ concentrations. Purification is important in enzyme profiling which helps in increasing the ChE reactivity towards targeted toxicants. Further tests in the future using Native polyacrylamide gel electrophoresis (Native-PAGE) would better support the results obtained from ion-exchange chromatography (Hayat et al., 2015).

\section{Substrate Specificity Profiling}

Figure 2 shows hydrolyzation of three synthetic substrates (ATC, BTC, PTC) each with increasing concentration from $1 \mathrm{mM}$ to $5 \mathrm{mM}$ obeying Michaelis-Menten plot. All three substrates displayed similar increases in hydrolytic activity along with the increase in concentration. However, it can be observed that $\mathrm{ChE}$ activity starts to reach plateau nearing the $5 \mathrm{mM}$ concentration. There is a clear significant difference to which substrate $\mathrm{ChE}$ from the D. hystrix brain reacts to. The curve indicated that ATC had the highest ChE activity, followed by PTC and lastly BTC. Following further analysis in Table 2, ATC displayed the lowest $\mathrm{K}_{\mathrm{m}}$ value, thus having the highest affinity towards ChE from D. hystrix brain compared to BTC and PTC. Although PTC indicated a high $\mathrm{V}_{\max }$ value, its catalytic efficiencies $\left(\mathrm{V}_{\max } / \mathrm{K}_{\mathrm{m}}\right)$ still fall short in comparison to ATC. Both data indicated that ATC is the most favored substrate of ChE from D. hystrix brain, followed by PTC and BTC. This also suggests that the ChE obtained in the brain was mostly AChE. 


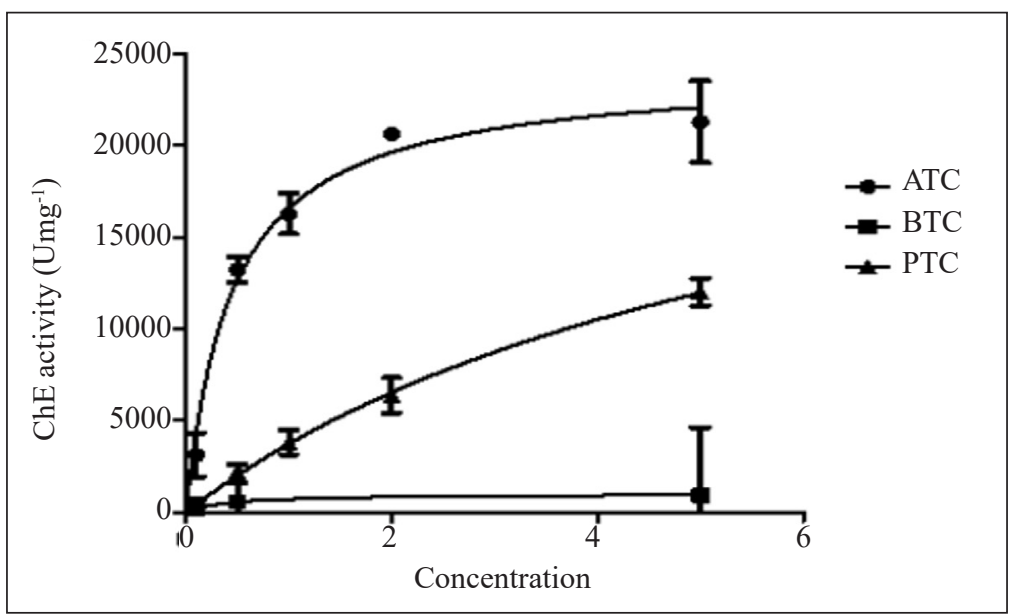

Figure 2. ChE profile on substrate specificity using three synthetic substrates (ATC, BTC, PTC). Error bar represented by mean \pm standard error $(n=3)$.

Table 2

Table of comparison of ATC, BTC and PTC on their maximum velocity $\left(V_{\max }\right)$, biomolecular constant $\left(K_{m}\right)$ and catalytic efficiencies $\left(V_{\max } / K_{m}\right)$ with $C h E$ from the brain tissue of $\mathrm{D}$. hystrix

\begin{tabular}{lccc}
\hline \multicolumn{4}{c}{ Mean point $(\mathbf{9 5 \%}$ confidence intervals) } \\
\hline Substrate & ATC & BTC & PTC \\
\hline $\mathbf{V}_{\max }(\boldsymbol{\mu m o l} / \mathbf{m i n} / \mathbf{m g})$ & 981.10 & 1547.00 & 3633.00 \\
$\mathbf{K}_{\mathrm{m}}(\mathbf{m M})$ & 0.07 & 2.33 & 1.33 \\
Catalytic efficiencies $\left(\mathbf{V}_{\max } / \mathbf{K}_{\mathbf{m}}\right)$ & 14015.71 & 663.95 & 2731.58 \\
\hline
\end{tabular}

To further discuss, in the study done by Sabullah et al., (2014) on P. javanicus liver tissue, ChE was found to be specific towards BTC with $\left(\mathrm{V}_{\max } / \mathrm{K}_{\mathrm{m}}\right)$ higher than ATC and PTC. However, a study on M. albus brain tissue by Khalidi et al. (2019) found that ATC had the highest $\left(\mathrm{V}_{\max } / \mathrm{K}_{\mathrm{m}}\right)$, similar to the result obtained in this study. These results proved that different parts of organs and different species of fish incorporated $\mathrm{ChE}$ with different substrate specificity of either ATC, BTC or PTC.

\section{Profiling of Optimum pH and Temperature}

Figure 3 shows the $\mathrm{pH}$ profile of ChE in overlapping buffer system of acetate buffer, sodium phosphate buffer and Tris-HCl buffer. The highest $\mathrm{ChE}$ activity was indicated at $\mathrm{pH} \pm(7.45-$ 7.50) for both sodium phosphate buffer and Tris-HCl buffer with no significant difference between the two values. Similarly, both buffers showed a decline in enzyme activity, starting from $\mathrm{pH} 8.0$ to 9.0. The pattern in Figure 3 indicates that ChE from D. hystrix is optimum and can be regulated in both sodium phosphate buffer and Tris- $\mathrm{HCl}$ buffer at $\mathrm{pH}$ 7.45 to 7.50. However, due to Tris-HCl high sensitivity towards temperature (AppliChem, 2008), sodium phosphate buffer is more suitable to be used for enzyme profiling. These 
attributes are also dependent on the $\mathrm{pK}_{\mathrm{a}}$ value of the buffer, which determines the range in which the buffer is considered adequate. Sodium phosphate buffer thus fits perfectly to optimize ChE from D. hystrix brain tissue with its $\mathrm{pK}_{\mathrm{a}}$ value falls in the range of 5.8 to 8.0.

In Figure 4, ChE enzyme activity with different temperatures was displayed. Optimum temperature was at $40^{\circ} \mathrm{C}$ where a steady increase in enzyme activity could be observed from 20 to $40^{\circ} \mathrm{C}$ but no significant difference was observed ( $>0.05$ ). Similar to other enzymes, kinetic energy increases as temperature increases, thus resulting in higher enzyme activity. However, a sharp decline of enzyme activity was shown at higher temperature presumably due to denaturation of the biological shape of ChE resulting in a bell-shaped curve. The ChE starts to denature when the temperature is higher than its optimum temperature (Ahmad et al., 2016) which in this study was at temperature $>40^{\circ} \mathrm{C}$.

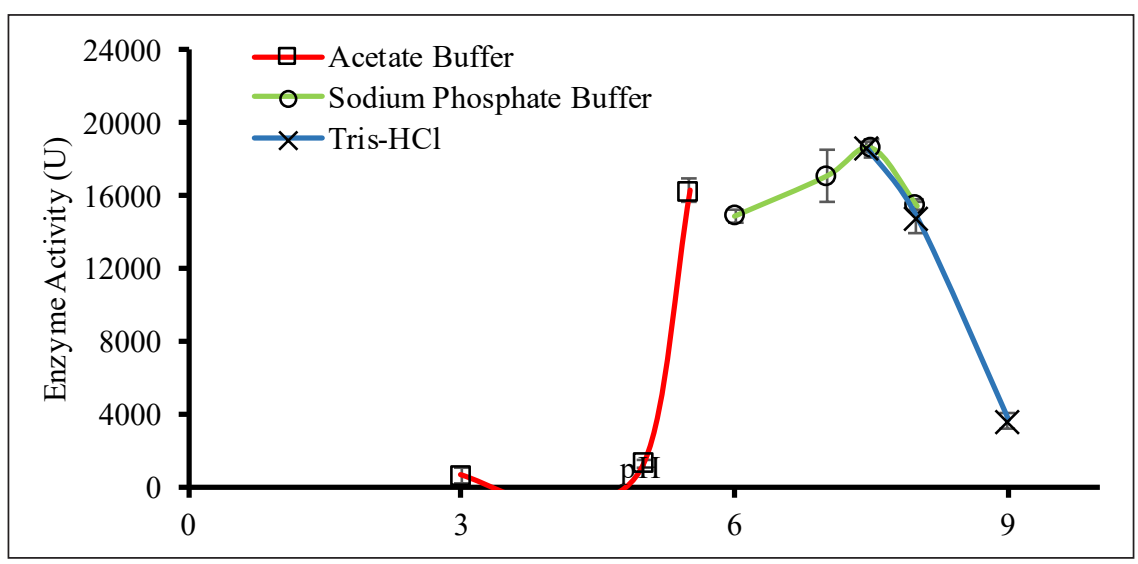

Figure 3. $\mathrm{pH}$ profile of $\mathrm{ChE}$ from $D$. hystrix brain tissues through overlapping buffer system of three different buffers (acetate buffer, sodium phosphate buffer and Tris-HCl buffer) with error bar represented by mean \pm standard deviation $(\mathrm{n}=3)$

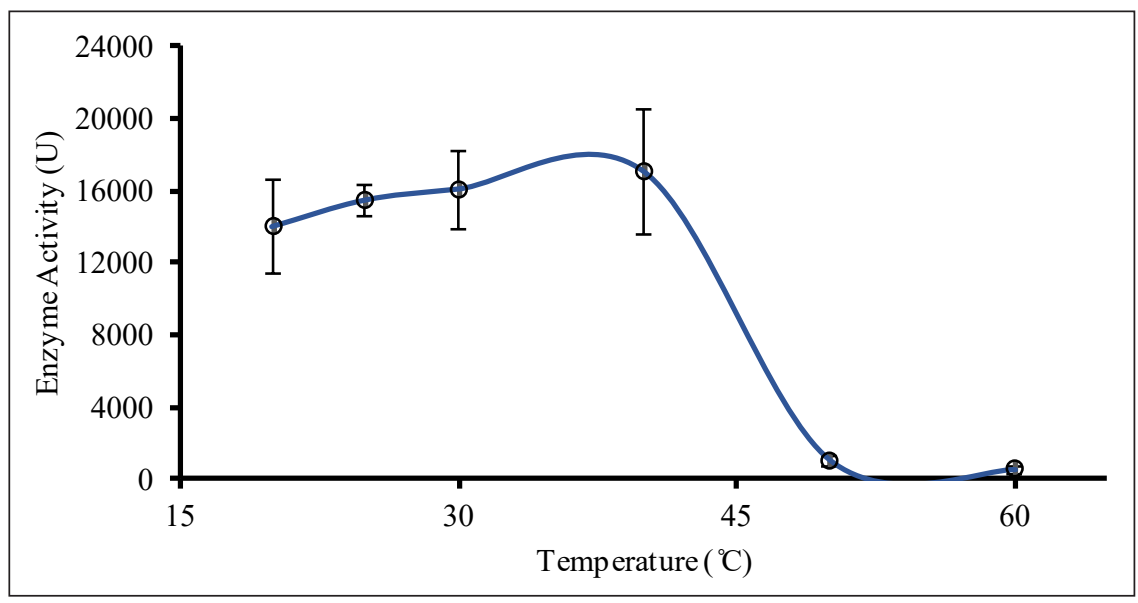

Figure 4. Temperature profile of ChE from D. hystrix brain tissues with error bar represented by mean \pm standard deviation $(\mathrm{n}=3)$ 
Similar to its substrate specificity, ChE extracted from different sources may or may not exhibit similar optimum $\mathrm{pH}$ and temperature. In this case, two studies by Ahmad et al. (2016) that evaluated the brain tissue of Tor tambroides ${ }^{\mathrm{b}}$ and liver tissue of Anabas testudineus $^{\mathrm{a}}$ showcased that $\mathrm{AChE}$ optimum temperature was in the range of 25 to $35^{\circ} \mathrm{C}$ for T. tambroides, falling into the same temperature range in this study. A. testudineus AChE showed an optimum temperature of $40^{\circ} \mathrm{C}$, similar to the result obtained in this study despite using different organs and species, thus further solidifying the point made.

\section{ChE Inhibitory Assay}

Figure 5 shows the reactivity of ChE enzyme from $D$. hystrix brain tissue towards the inhibitory effect of bendiocarb, propoxur, methomyl, carbofuran and carbaryl at $10 \mathrm{ppm}$ concentration. All of the carbamates elicit inhibitory activities higher than $85 \%$ with highest in methomyl at $98 \%$. The strength of carbamate inhibitory activities are as follows; met homyl $>$ carbofuran $>$ bendiocarb $>$ carbaryl $>$ propoxur. According to Sabullah et al. (2015), in comparison to organophosphate, which can also inhibit $\mathrm{ChE}$, carbamates bind to $\mathrm{AChE}$ esoteric sites without the need of any bioconversion. This study implied that carbamatesbased pesticide could bind to AChE more easily than organophosphate. All of the tested carbamates are applied as a broad-spectrum insecticide that could kill more than one species of insects. In concurrent to their applications, methomyl and carbofuran are mainly used in fields and crops whereas bendiocarb, carbaryl and propoxur were also found in household pest control. It was stated by Gupta et al. (2011) that methomyl and carbofuran were highly dangerous towards any living system and this statement was further supported by Dorko et al. (2011) indicating that insecticides applied as household pest control had lower toxicity towards vertebrates. A study carried out by Mahboob et al. (2014) on Labeo rohita found

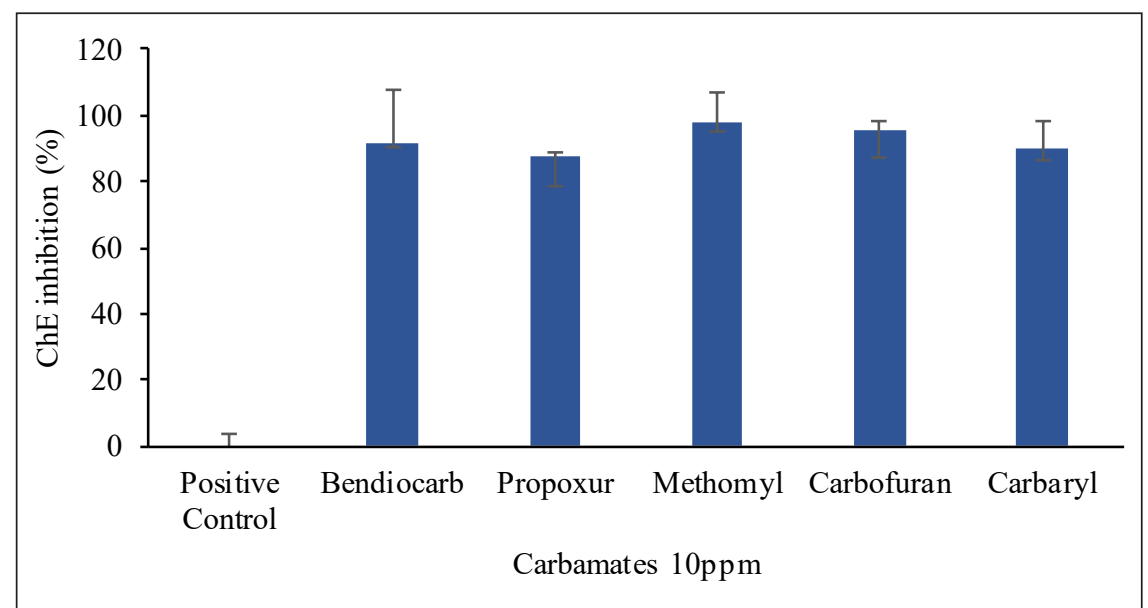

Figure 5. Inhibition test profile of five different types of carbamates at 10ppm concentration on ChE from $D$. hystrix brain tissues with error bar represented by mean \pm standard deviation $(n=3)$ 
that carbofuran exposure disrupted the functions of organs that included the brain, gills, muscle, kidney, liver and even non-organs such as blood. These multiple findings thus solidified the result and present a logical explanation to why methomyl and carbofuran have the highest inhibitory activities in comparison to the other carbamates.

\section{CONCLUSION}

The extraction of cholinesterase (ChE) enzyme from the brain tissues of $D$. hystrix was achieved using DEAE-Sepharose ion-exchange chromatography. Through substrate specificity test, it was observed that the partially purified ChE enzyme was proned towards ATC with lowest $\mathrm{K}_{\mathrm{m}}$ value $(0.07011 \mathrm{mM})$ and highest catalytic efficiency value of $13993.72\left(\mathrm{~V}_{\max } \mathrm{K}_{\mathrm{m}}{ }^{-1}\right)$. The optimum $\mathrm{pH}$ was in the range of $\mathrm{pH} \pm 7.45$ and 7.5 with an optimum temperature at 20 to $40^{\circ} \mathrm{C}$. ChE inhibitory assay showed all pesticides were able to inhibit ChE of $D$. hystrix with methomyl having the highest inhibiting ability at $98 \%$, while propoxur with the lowest inhibition rate. This study proved that the extraction and partial purification of $\mathrm{ChE}$ from the brain tissues of $D$. hystrix were efficient and were able to show high reactivity towards carbamates inhibitory activities without applying higher cost consuming methods such as the HPLC. This also implies that ChE from D. hystrix brain tissues can be applied as a biomarker tool due to its ability in detecting carbamates inhibitory activities with the change in color following the Ellman assay principles. Further analysis regarding this enzyme on the wider variety of toxicants can help determine the efficacy of it as a biomarker.

\section{ACKNOWLEDGEMENT}

Acknowledgment towards University Malaysia Sabah for Skim Dana NIC, SDN0020-2019.

\section{REFERENCES}

Acikara, O. B. (2013). Ion-exchange chromatography and its applications. In Martin, D. F., \& Martin, B. B. (Ed.), Column chromatography (pp. 31-58). Rijeka, Croatia: InTech .

Ahmad, S. A., Sabullah, M. K., Yasid, N. A., Shamaan, N. A., Abd Shukor, M.Y., Jirangon, H., ... \& Syed, M.A. (2016). Evaluation of acetylcholinesterase source from fish, for detection of carbamate. Journal of Environmental Biology, 37(4), 479-484.

Ahmad, S. A., Wong, Y. F., Shukor, M. Y., Sabullah, M. K., Yasid, N. A., Hayat, N. M., ... \& Syed, M. A. (2016). An alternative bioassay using Anabas testudineus (Climbing perch ) colinesterase for metal ions detection. International Food Research Journal, 23(4), 1446-1452

Almroth C., Sturve, B., Stephensen, J., Fredrik Holth, E., \& Forlin, L. (2008). Protein carbonyls and antioxidative defenses in corkwing wrasse (Symphodus melops) from a heavy metal-polluted and PAHpolluted site. Marine Environment Research, 66, 271-277. doi:10.1016/j.marenvres.2008.04.002 
AppliChem. (2008). Biological buffers. Darmstadt, Germany: PanReac AppliChem ITW Reagents.

Assis, C. R., Linhares, A. G., Oliveira, V. M., Franca, R. C., Carvalho, E. V., Bezerra, R. S., \& de Carvalho Jr, L. B. (2012). Comparative effect of pesticides on brain acetylcholinesterase in tropical fish. Science of the Environment, 441, 141-150. doi:10.1016/j.scitotenv.2012.09.058

Berman, T. T., Goen, T., Novack, L., Beacher, L., Grinshpan, L., Segev, D., \& Tordjman, K. (2017). Corrigendum to urinary concentrations of organophosphate and carbamate pesticides in residents of a vegetarian community. Environment International, 96(2016), 34-40. doi: 10.1016/j.envint.2017.06.017

Bon, S., and Rieger, F. (1975). Interactions between lectins and electric eel acetylcholinesterase. FEBS Letters, 53(3), 282-286. doi:10.1016/0014-5793(75)80037-8

Bradford M. M. (1976). A rapid and sensitive method for the quantitation of microgram quantities of protein utilizing the principle of protein dye binding. Analytical Biochemistry, 72(1-2), 248-254. doi:10.1016/0003-2697(76)90527-3

Darvesh, S., Darvesh, K. V., McDonald, R. S., Mataija, D., Walsh, R., Mothana, S., ... \& Martin, E. (2008). Carbamates with differential mechanism of inhibition toward acetylcholinesterase and butyrylcholinesterase. Journal of Medicinal Chemistry, 51(14), 4200-4212. doi:10.1021/jm8002075

Dorko, F., Danko, J., Flešárová, S., Boroš, E., \& Sobeková, A. (2011). Effect of pesticide bendiocarbamate on distribution of acetylcholine- and butyrylcholine-positive nerves in rabbit's thymus. European Journal of Histochemistry, 55(4), 1-4. doi:10.4081/ejh.2011.e37

Ellman, G. L., Courtney, K. D., Andres, V. J., \& Featherstone, R. M. (1961). A new and rapid calometric determination of acetylcholinesterase activity. Biochemical Pharmacology, 7(2), 88-95. doi:10.1016/00062952(61)90145-9

Gonzalez, C., Greenwood, R., \& Quevauviller, P. (2009). Rapid chemical and biological techniques for water monitoring. In Gonzalez, C., Greenwood, R., \& Quevauviller, P. (Ed.), Rapid chemical and biological techniques for water monitoring (pp. 1-419). United Kingdom: Wiley Blackwell.

Gupta, R. C., Malik, J. K., \& Milatovic, D. (2011). Organophosphate and carbamate pesticides. In Gupta, R. C. (Ed.), Reproductive and developmental toxicology (pp. 471-486). Georgia, USM: Elsevier.

Hayat, N. M., Shamaan, N. A., Shukor, M. Y., Sabullah, M. K., Syed, M. A., Khalid, A., ... \& Ahmad, S. A. (2015). Cholinesterase-based biosensor using Lates calcarifer (Asian Seabass) brain for detection of heavy metals. Journal of Chemical and Pharmaceutical Sciences, 8(2), 376-381.

Khalidi, S. A. M., Sabullah, M. K., Sani, S. A., Ahmad, S. A., Shukor, M. Y., Jaafar, I. N. M., \& Gunasekaran, B. (2019). Acetylcholinesterase from the brain of Monopterus albus as detection of metal ions. Journal of Physics: Conference Series, 1358, 1-11. doi:10.1088/1742-6596/1358/1/012028

Mahboob, S., Ahmad, L., Sultana, S., AlGhanim, K., Al-Misned, F., \& Ahmad, Z. (2014), Fish cholinesterases as biomarkers of sublethal effects of organophosphorus and carbamates in tissues of Labeo rohita. Journal of Biochemical and Molecular Toxicology, 28(3), 137-142. doi:10.1002/jbt.21545

Monserrat, J. M, Bianchini, A., \& Bainy, A. C. D. (2002). Kinetic and toxicological characteristic of acetylcholinesterase from the gills of oyster (Crassostrea rhizophorea) and other aquatic species. Marine Environment Research, 54(3-5), 781-785. doi:10.1016/s0141-1136(02)00136-8 
Quilichini, Y., J. Foata, J. Justine, R. Bray, B. Marchand. (2010). Ultrastructural study of the spermatozoon of Heterolebes maculosus (Digenea, Opistholebetidae), a parasite of the porcupinefish Diodon hystrix (Pisces, Teleostei). Parasitology International, 59(3), 427-434. doi:10.1016/j.parint.2010.06.002

Rosenberry, T. L., Brazzolotto, X., Macdonald, I. R., Wandhammer, M., Trovaslet-leroy, M., Darvesh, S., \& Nachon, F. (2017). Comparison of the binding of reversible inhibitors to human butyrylcholinesterase and acetylcholinesterase: A crystallographic, kinetic and calorimetric study. Molecules, 22(12), 1-21. doi:10.3390/molecules22122098

Sabullah, M. K., Ahmad, S. A., Shukor, M. Y., Shamaan, N. A., Khalid, A., Gansau, A. J., ... \& Sulaiman, M. R. (2015). Acetylcholinesterase from Puntius javanicus for the detection of carbamates and organophosphates. Journal of Chemical and Pharmaceutical Sciences, 8(2), 348-353.

Sabullah, M. K., Sulaiman, M. R., Shukor, M. Y. A., Syed, M. A., Shamaan, N. A., Khalid, A., \& Ahmad, S. A. (2014). The assessment of cholinesterase from the liver of Puntius javanicus as detection of metal ions. Scientific World Journal, 2014, 1-9. doi:10.1155/2014/571094

Sturm, A., Wogram, J., \& Segner, H. (2000). Different sensitivity to organophosphates of acetylcholinesterase and butyrylcholinesterase from three-spined stickleback (Gasterosteus aculeatus): Application in biomonitoring. Environmental Toxicology and Chemistry: An International Journal, 19(6), 1607-1615. doi:10.1002/etc.5620190618 